\title{
THE PROTOTYPE DEVELOPMENT OF CREATIVE THINKING SKILLS MODEL'S BOOK
}

\author{
I Gusti Ayu Tri Agustiana ${ }^{1)}$, Rudiana Agustini ${ }^{2),}$ Muslimin Ibrahim ${ }^{3)}$ \\ 1) Elementary School Education of Department Universitas Pendidikan Ganesha Bali Indonesia \\ ${ }^{2)}$ Chemistry Education of Department, State University of Surabaya \\ 3) Biology Education of Department, State University of Surabaya \\ Jl. Udayana No.12 Singaraja Bali \\ Email : igustiayutriagustiana@yahoo.co.id
}

\begin{abstract}
Model of book is an important part of the research process in developing creative thinking skills. Considering the importance of creative thinking skills, it is necessary to attempt developing such skills in the learning process by applying an appropriate and effective model. This research will develop the components of learning model that includes theoretical rationale, syntax, social systems, reaction principle, support systems, and the impact instructional companion. Learning model of science is developed with syntax orientation, excavation creative ideas, research, elaboration, presenting the results of the work, evaluation, and implementation (OPPEMEI) with indicators of creative thinking skills fluency, flexibility, originality, elaboration and evaluation. To achieve the goals, it should need a couple of steps, namely (1) analyzing and providing a rational basis to support the development of learning model for creative thinking skills. (2) analyzing and constructing the theories that support the development of the model. Some synthesis theories for reviews are a constructivism theory, creative thinking theories, a motivation theory, a theory of Vygotsky (the theory of socio-cultural) and cognitive theory, (3) Analyzing the flow of thought decrease hypothetical OPPEMEI Model, (4) providing guidelines for the implementation of learning using OPPEMEI learning model, (5) conducting Focus Group Discussions (FGDs) and (6) Revisions. Validity is assessed by expert judges in terms of content validity and construct validity. The construct validity includes the logic of stage model (syntax) and the support of relevant theory at each stage. Validation of the content reflects the state of the art or the strength of the device and the content materials are assessed based on the conformity with the applicable curriculum. The learning model is stated valid, if the expert judges and practical say that the model is developed based on strong and latest theoretical rationale and there is consistency between the components.
\end{abstract}

Keywords: creative thinking skills, OPPEMEI Model

\section{INTRODUCTION}

Creative thinking skills are a factor that will support the children's creativities, and it is believed as a embryo of human resources (Albert, 2016; Munandar, 2009). The superior human resources have the characteristics of high productivity (efficiency, effectiveness, and innovation) (Bono, 2015), Amabile (as cited in Nur, 2014) showed that the key aspects of creative thinking are 1) Happy or entertained when the children have different opinions with the others and trying the deviate solutions from status quo (the social situations nowadays). (2) Combining knowledge 
that is from many kinds of area that separate before. (3) The students' ability to continue in solving the difficult and not attractive problems. (4) The ability to leave a method and come again with a fresh perspective (incubation). These conditions can prompt the children creating kinds of mindset. Those varieties appear because the areas of creative thinking skills are given to students depend on the appropriate learning model that are applied (Arend, 2012). The learning models that are set depend on the purpose of the learning process. Creativity can be created with scientific approaches (Permendikbud No. 23 tahun 2016). That is why, the use of model is determined by the characteristics of materials that are going to be learned.

Natural sciences (IPA) related with the way how to know about nature systematically by using scientific methods, so IPA is not only about mastering the knowledge, but also as an inquiry process. Therefore, teachers should be able to bring phenomena of nature into the classroom' activities, then their students are expected could more know about themselves and the environment around them. So, the goals of learning IPA is it should teach students in producing a product and the process for it, and also unconsciously it can build creative thinking skills for students. Based on these perspectives, a model that could support the development of creative thinking skills in the natural sciences (IPA) learning will become urgent (Lin \& Shih 2016).

All this time, the contextual stimulations that are used to find the creative thinking skills are not optimally implemented in varieties of natural learning (IPA) such as (1) The learning model of problem based learning (Wijnia et al. 2016; Allen et al. 2011; Nuttariya et al. 2012), (2) The Brain Based Learning (BBL) model (Eagleton \& Muller 2011), (3) Inquiry model (Hong et al. 2014; Lederman et al. 2014; Lehtinen, 2016).

Thinking creatively is a main model of OPPEMEI in which this model becomes an important model. That condition can be seen from the steps of OPPEMEI Model that consist of (1) Orientation, (2) Extracting creative thinking, (3) Investigation, (4) Elaboration, (5) Developing and presenting results of the work, (6) Evaluating for the process of the product, (7) Implementation. The use of this model comes from the theory of cognitive motivation, this theory is believed that individuals prompted to do some actions based on their mind if the students are given stimulus with varieties of contextual problems, so it can build a deeper understanding.

The purpose of learning model that is able to train the students' skills as stocks that will be used to analyze and evaluate data so further the students are able to explain scientifically the 
nature phenomena in which are in same steps with OPPEMEI Model. Therefore, it can help students in developing and using the habit of creative thinking skills, understanding the material of IPA, and giving chances for students to take parts during the science process.

Beside that, OPPEMEI model can build students' character. This condition is appropriate with the main purpose of Undang-undang Nomer 20 Tahun 2003 about National Education System that is expected can create a developing process in which show the quality of students' characters as the next generation for nation in the future, moreover in facing challenges in $21^{\text {st }}$ century known as century of knowledge, knowledge based on society with its principles those are (1) Instruction should be student-centered, (2) Education should be collaborative, (3) Learning should have context, (4) Schools should be integrated with society. In the productivity's demotions, OPPEMEI Model is in the same way with the purpose of Curriculum 2013 in which an education process can produce productive, creative, innovative, and effective society in Indonesia through strengthening attitudes and integrated knowledge (Yasa, 2014).

The development of OPPEMEI model is in the same way with Permendikbud No. 20 Tahun 2016, a graduate competent standard for elementary school and junior high school, explain that every graduate of elementary school and junior high school should have competences for three dimensions namely attitudes, knowledge, and skills (Chapter II). For skills' dimension in which students should have skills in thinking and doing, those are creative, productive, critical, independent, collaborative, and communicative through scientific approaches that are appropriate for the development of students in which are relevant with the given tasks.

In the content aspects, the development of OPPEMEI learning model emphasizes the achievement of creative thinking skills based on Permendikub No. 21 Tahun 2016 which is about the context standard of elementary school and junior high school, ask the students should be able to show the skills of reasoning, processing, and presenting effectively, creatively, productively, critically, independently, collaborating, communicatively, and solution. In the concrete and abstract areas are about the development of what they have learned in the school and enable to use the method based on scientific rules.

In the aspect of process, the development of OPPEMEI learning model emphasize on the achievement of creative thinking skills based on Permendikub No. 22 Tahun 2016 in which strengthen the scientific approaches (scientific), integrated thematic (thematic between subjects), and thematic (between a subject) that need applying a subject which is provided with attitudes 
or research (discovery/inquiry learning). In order to prompt the students' ability in producing a contextual product, both individual and groups so then it is really suggested to use an approach that can produce a product based on the problems (project based learning), by the governments' rules in this case students should learn about ideas, solving problems, applying what they have learned, giving opinions, doing a trial, and doing monitoring (Sapurto, 2015). This condition is appropriate with Permendikbud in which assessing skills are done through practices, products, projects, portfolios, and/or other techniques based on the assessed competences; No. 23 tahun 2016 about assessment standard that will measure.

Based on some analysis of learning models that have been implemented in IPA learning in order to increase creative thinking skills, and cognitive understanding about the concept of science learning for students as the candidate teachers of elementary school, so it needs to formulate a hypothetical model that emphasizes some aspects such as (1) focusing orientation in the early stage of learning, (2) There is extracting ideas that can make students feel challenging for their cognitive, (3) Investigative aspects are to solve creative problems, (4) An aspect in which students share their ideas (elaboration), (5) An aspect of developing and producing a product, (6) An aspect of evaluation as reflection and revision, and the last is (7) The aspect of Implementation. Formulating those aspects can be a learning model that should be analyzed more.

Those principles are a new touch in science learning, especially basic natural science (IPA) for students that will become a teacher namely OPPEMEI learning model in which has seven phases namely (1) Orientation, (2) Extracting creative ideas, (3) Investigation (4) Elaboration, (5) Developing and serving results of the work, (6) Evaluating the process of the product, and (7) Implementation. The use of this model comes from the theory of cognitive, this theory believe that individuals prompt to do actions from their mind. The theory of attribution, according to Arend (2012), is the way how the individuals understand and predict the cause of success or failures that can be a motivation. Relating with the efforts in applying OPPMEI Model approach, so the explanation of this article is done by developing a prototype book about learning model of creative thinking skills. By the content validity concept that focus on the existence of a need for the intervention and its design is based on state-of the-art (scientific) knowledge (Nieveen, 2010). In addition, the intervention of this research is OPPEMEI Model. 
The purposes of this research are (1) Assessing content validity of Orientation Model, extracting the creative ideas, Investigation, Elaboration, Presenting the results, and Evaluating the implementation (OPPEMEI) in terms of (1) rational development model, and (2) The design of this model based on the latest knowledge. (2) Measuring the validity in extracting creative thinking model, Investigation, Elaboration, Presenting the results, and Evaluating the implementation (OPPEMEI) in terms of consistency, and the logic of the model's components internally.

\section{METHOD}

The design of this research is developing research (Development and Research). The validity of learning is done through Focus Group Discussion (FGD) by five expert judges. OPPEMEI Model is valid if the result of validity can fulfill the criteria. The criteria are (1) The expert judges stated that OPPEMEI model is based on theory of learning or strong rational theory (Content Validity), (2) Expert judges stated that the components of OPPEMEI model consistently relate each other (Construct Validity).

The analysis of OPPEMEI Model's validity is done by doing a recapitulation towards the expert judges' statements, finding out the average results of all expert judges, finding out the total of average, the categories of validity are set based on the categorization criteria of quality model in which are adapted from categorizing according (Bloom et al. 1956) as follows: $4,5 \leq$ model $\leq 5,0$ extremely valid, $3,5 \leq$ model $<4,5$ valid, $2,5 \leq$ model $<3$, valid enough, $1,5 \leq$ model $<2,5$ less valid, model $<1,5$ not valid.

The criteria that are used to decide whether the OPPEMEI has sufficient degree of validity or not is if the model of validity is in valid category. If the stage of validity's achievement is lower that the valid category it means that, the model needs revision based on the expert judges' suggestions. Further, the validity is done again. The process continuously as well until the ideal OPPEMEI model is achieved.

\section{RESULTS AND DISCUSSION}

A. The results of content validity for OPPEMEI Model in terms of some aspects as follows: (a) The rational development of OPPEMEI Model, (b) OPPEMEI Model is designed based on the latest knowledge. 
B. The rational development of OPPMEI Model

\begin{tabular}{|c|c|c|c|c|c|c|c|}
\hline \multirow[t]{2}{*}{ No } & \multirow[t]{2}{*}{ The aspects of the Assessments } & \multicolumn{5}{|c|}{$\begin{array}{c}\text { Expert judge's } \\
\text { assessment }\end{array}$} & \multirow{2}{*}{$\begin{array}{c}\text { Skor } \\
\text { Rerata }\end{array}$} \\
\hline & & 1 & 2 & 3 & 4 & 5 & \\
\hline 1 & $\begin{array}{l}\text { The development of OPPEMEI Model aims to } \\
\text { increase creative thinking skills and the result of } \\
\text { students' learning process as a need of primary } \\
\text { graduate competences for the elementary school } \\
\text { teachers' candidates }\end{array}$ & 4 & 5 & 4 & 4 & 5 & 4.4 \\
\hline 2 & $\begin{array}{l}\text { The development of OPPEMEI Model uses } \\
\text { scientific and inquiry approaches based on } \\
\text { Permendikbud Nomor } 49 \text { Tahun } 2014 \text { about the } \\
\text { national standard of higher education in which } \\
\text { emphasizes that the learning process should give } \\
\text { priority to the use of scientific approaches, so it } \\
\text { can achieve the academic environment based on } \\
\text { system of values, norms, and knowledge' rules. }\end{array}$ & 4 & 3 & 4 & 5 & 5 & 4.2 \\
\hline 3 & $\begin{array}{l}\text { The development of OPPEMEI Model bridges the } \\
\text { gap between a hope of graduate competences' } \\
\text { needs based on standard competencies of } \\
\text { Elementary Schools' teachers in which they are } \\
\text { able to develop curriculum and learning process } \\
\text { creatively and innovatively at Elementary Schools. }\end{array}$ & 5 & 4 & 5 & 4 & 5 & 4.6 \\
\hline 4 & $\begin{array}{l}\text { The development of OPPEMEI Model based on a } \\
\text { recommendation in improving the innovative } \\
\text { learning model that centered in the university } \\
\text { students such as PBL, BBL and inquiry. }\end{array}$ & 4 & 5 & 5 & 4 & 4 & 4.4 \\
\hline 5 & $\begin{array}{l}\text { The development of OPPEMEI Model really } \\
\text { supports the government's programs in order to } \\
\text { improve the competence of higher education } \\
\text { graduates creatively and responsibly that have } \\
\text { been set on Peraturan Pemerintah RI Nomor } 8 \\
\text { Tahun } 2012 \text { about KKNI, Permendikbud Nomor } \\
73 \text { Tahun } 2013 \text { about the application of KKNI for } \\
\text { higher education and Permendikbud nomor } 49 \\
\text { tahun } 2014 \text { about the national standard of higher } \\
\text { education. In which it emphasizes that the } \\
\text { universities should give a space in developing } \\
\text { creativities. }\end{array}$ & 5 & 5 & 5 & 4 & 5 & 4.4 \\
\hline
\end{tabular}


C. OPPEMEI Model is designed based on the latest Knowledge

\begin{tabular}{|c|c|c|c|c|c|c|c|}
\hline \multirow[t]{2}{*}{ No } & \multirow[t]{2}{*}{ The aspects of the Assessment } & \multicolumn{5}{|c|}{$\begin{array}{l}\text { The expert } \\
\text { judge's } \\
\text { assessment }\end{array}$} & \multirow[t]{2}{*}{$\begin{array}{c}\text { Skor } \\
\text { Rerata }\end{array}$} \\
\hline & & 1 & 2 & 3 & 4 & 5 & \\
\hline 1 & $\begin{array}{l}\text { The development of OPPEMEI Model uses the main } \\
\text { sources from international journals. By revising the } \\
\text { weakness from PBL Model, BBL, and inquiry those } \\
\text { are 1) the time that take too long (Lam, 2004), 2) } \\
\text { formulating hypothesis was difficult to be done in } \\
\text { conditions without cooperation (Soltis, et al, 2015), 3) } \\
\text { exploration is in PBL usually widened and expanded } \\
\text { (Ross \& Hurlbert, 2004), without a presentation of } \\
\text { coherent data, so the creativity of students are low } \\
\text { (Caine, 1995), 4) If the production of report do not } \\
\text { provide with facts, data, and a theory, so it makes the } \\
\text { ability to keep their ideas weak (Kuby, 2003), 5) There } \\
\text { is not a stage that is used to show their products, so it } \\
\text { effect their understanding that are still low (Osgood- } \\
\text { Campbell 2015), 6) If the incubation process is not } \\
\text { verified on the aspect of assessment process and } \\
\text { students' understanding product are low (Osgood- } \\
\text { Campbell 2015). 7) If the concept is not optimally } \\
\text { applied in the everyday life, then the students' creative } \\
\text { thinking skills will be low (Caine 1995). }\end{array}$ & 3 & 4 & 5 & 5 & 4 & 4.2 \\
\hline 2 & $\begin{array}{l}\text { The development of OPPEMEI Model uses the } \\
\text { creative thinking skills theory, motivation theory } \\
\text { (ARCS Model), cognitive learning theory (Meta } \\
\text { cognitive), the theory of complex cognitive processes } \\
\text { (Creativity and problem solving), theory of mind- } \\
\text { centered learning and constructivism (observational } \\
\text { learning, the reciprocal causation model, } \\
\text { constructivism, and scaffolding) from an standard and } \\
\text { up-to-date education psychology book namely } \\
\text { education psychology book written by (Moreno 2013), } \\
\text { (Arends 2012) and (Kauchak \& Eggen 2013). }\end{array}$ & 4 & 5 & 4 & 5 & 5 & 4.6 \\
\hline 3 & $\begin{array}{l}\text { The development of OPPEMEI Model uses empiric } \\
\text { foundation from international and up-to-date journals } \\
\text { in which the researches' results by (Hmelo-silver, } \\
\text { 2013; Lin \& Bruce, 2013; Osgood-Campbell, 2015; } \\
\text { Soltis et al., 2015); Talib, 2014) }\end{array}$ & 5 & 5 & 5 & 5 & 4 & 4.8 \\
\hline 4 & $\begin{array}{l}\text { The development of OPPEMEI Model more uses } \\
\text { references to the latest research journals rather than } \\
\text { reference books. }\end{array}$ & 4 & 5 & 5 & 4 & 4 & 4.4 \\
\hline
\end{tabular}


5 The development of OPPEMEI Model's planning pays attention on the KKNI competences organize learning that requires the use of ICT media and the use of technology such as laptop, LCD, and the smooth internet network.

6 The development of OPPEMEI Model's planning pays attention on the KKNI competences (Model Book) and organize learning that requires the use of ICT media and the use of technology such as laptop, LCD, and smooth internet network.

7 The development of OPPEMEI Model' assessment is adjusted with a modified theory of creative thinking skills from Munandar 2009) and (Guilford \& Christensen 1973).

The results of construct validation of OPPEMEI model are reviewed from some aspects as follows:

A. The overview of OPPEMEI Model

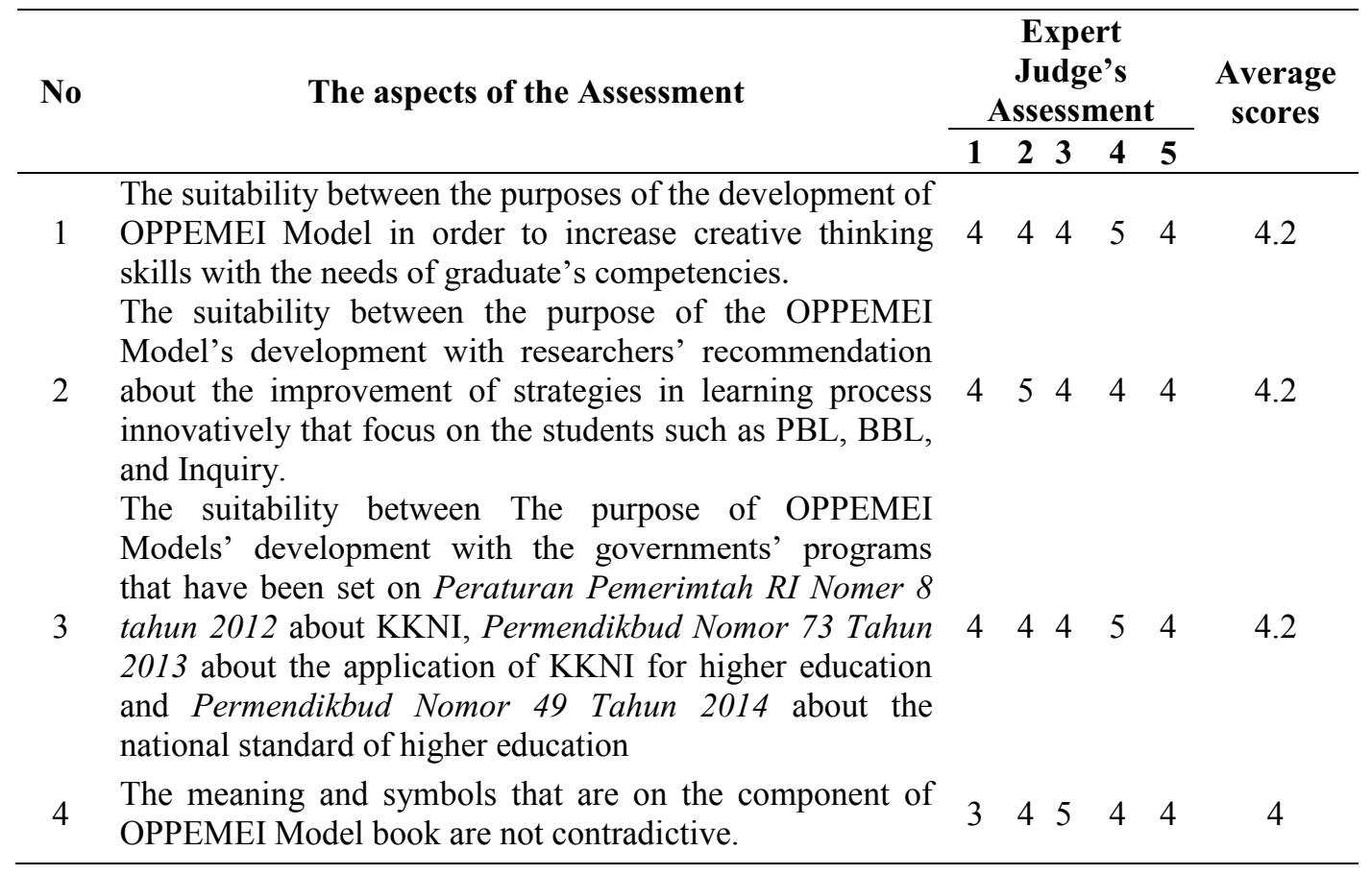


B. The Theoretical support and The empirical of OPPEMEI Model

\begin{tabular}{|c|c|c|c|c|c|c|c|}
\hline \multirow[t]{2}{*}{ No } & \multirow[t]{2}{*}{ The aspects of the Assessments } & \multicolumn{5}{|c|}{$\begin{array}{c}\text { Expert Judge's } \\
\text { Assessment }\end{array}$} & \multirow{2}{*}{$\begin{array}{c}\text { Average } \\
\text { scores }\end{array}$} \\
\hline & & 1 & 2 & 3 & 4 & 5 & \\
\hline \multirow{3}{*}{1} & The consistency of Phase 1: Oriented with: & & & & & & \\
\hline & Theoretical Foundation: & 4 & 4 & 5 & 4 & 4 & 4.2 \\
\hline & Empirical Foundation: & 4 & 4 & 4 & 4 & 5 & 4.2 \\
\hline \multirow{3}{*}{2} & $\begin{array}{l}\text { Consistency of Phase 2: Extracting creative ideas } \\
\text { with }\end{array}$ & & & & & & \\
\hline & Theoretical Foundation: & 4 & 3 & 4 & 5 & 4 & 4 \\
\hline & Empirical Foundation: & 4 & 4 & 4 & 4 & 4 & 4 \\
\hline \multirow{3}{*}{3} & Consistency of Phase 3: Investigating with & & & & & & \\
\hline & Theoretical Foundation: & 4 & 4 & 5 & 4 & 5 & 4.4 \\
\hline & Empirical Foundation: & 4 & 4 & 4 & 4 & 5 & 4.2 \\
\hline \multirow{3}{*}{4} & Consistency of Phase 4: Elaborating with & & & & & & \\
\hline & Theoretical Foundation: & 4 & 3 & 4 & 3 & 4 & 3.6 \\
\hline & Empirical Foundation & 4 & 4 & 4 & 4 & 4 & 4 \\
\hline \multirow{3}{*}{5} & Consistency of Phase 5: Presenting the result with & & & & & & \\
\hline & Theoretical Foundation: & 3 & 4 & 5 & 4 & 4 & 4 \\
\hline & Empirical Foundation: & 4 & 4 & 3 & 4 & 4 & 3.8 \\
\hline \multirow{3}{*}{6} & Consistency of Phase 6: Evaluating with & & & & & & \\
\hline & Theoretical Foundation: & 4 & 5 & 4 & 5 & 4 & 4.4 \\
\hline & Empirical Foundation: & 4 & 3 & 4 & 4 & 3 & 3.6 \\
\hline \multirow{3}{*}{7} & Consistency of Phase 7: Implementing with & & & & & & \\
\hline & Theoretical Foundation: & 4 & 4 & 3 & 4 & 4 & 3.8 \\
\hline & Empirical Foundation: & 3 & 4 & 3 & 3 & 3 & 3.2 \\
\hline
\end{tabular}

C. The OPPEMEI Model's Planning

\begin{tabular}{llllllll}
\hline \multirow{2}{*}{ No } & \multicolumn{1}{c}{ The aspects of the Assessments } & \multicolumn{3}{c}{ Penilaian Ahli } & Average \\
\cline { 3 - 6 } & & $\mathbf{1}$ & $\mathbf{2}$ & $\mathbf{3}$ & $\mathbf{4}$ & $\mathbf{5}$ & scores \\
\hline & $\begin{array}{l}\text { The consistency is in determining the basic } \\
\text { competencies, indicators, and learning objectives in } \\
\text { the field of university. }\end{array}$ & 4 & 4 & 4 & 5 & 4 & 4.2 \\
$\begin{array}{l}\text { The consistency of planning is in making creative } \\
\text { questions with an assessment in which measures } \\
\text { creative thinking skills on OPPEMEI that has been } \\
\text { developed by Hu \& Adey (2010). }\end{array}$ & 4 & 5 & 4 & 4 & 4 & 4.2 \\
2 & & & & & & &
\end{tabular}


The consistency of organizing resources

(Understanding the process of skills and the operation of media) and logistic (Students'

3 handbook, students' worksheets, smooth internet

$\begin{array}{llllll}4 & 4 & 4 & 5 & 4 & 4.2\end{array}$
network, and LCD availability) with pre-requisite in which will support the success of learning process with OPPEMEI Model.

D. The implementation of OPPEMEI Model

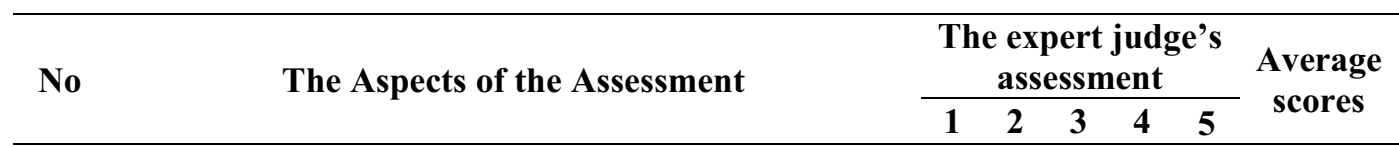

The phase of syntax can give a description about the

1 sequences of learning activities logically, systematically, and consistently. This is to achieve the $\begin{array}{llllll}4 & 4 & 4 & 5 & 5 & 4.4\end{array}$ goals of the OPPEMEI Model's development

The social systems are able to give a description about the parts of students and lecturers, the interaction

2 between students, the interaction between students and lecturer logically, and consistently achieve the goals of OPPEMEI Model's development

The reactionary principal gives a description the way the lecturers appreciate and respond the students'

3 behavior during learning process logically and consistently in order to achieve the goals of OPPEMEI Model's development

The supportive system (Syllabus, SAP, BAM, LKM, LP) and media (tools and materials of investigation,

4 ICT media, LCD, and smooth internet network logically that are able to support the smooth learning process with OPPEMEI Model

The impact of instructional consistently aims to develop OPPEMEI Model, and the impact of escort

5 unconsciously effect from the implementation of syntax, social systems, reactionary systems, and $\begin{array}{llllll}4 & 5 & 4 & 4 & 4 & 4.2\end{array}$ supportive systems of OPPEMEI Model 
E. The management of Learning environment

\begin{tabular}{|c|c|c|c|c|c|c|c|}
\hline \multirow[t]{2}{*}{ No } & \multirow[t]{2}{*}{ The Aspects of the Assessment } & \multicolumn{5}{|c|}{$\begin{array}{c}\text { Expert Judge's } \\
\text { Assessment }\end{array}$} & \multirow{2}{*}{$\begin{array}{c}\text { Average } \\
\text { scores }\end{array}$} \\
\hline & & 1 & 2 & 3 & 4 & 5 & \\
\hline 1 & $\begin{array}{l}\text { Learning environments are really important in } \\
\text { supporting the achievement for the goals of } \\
\text { OPPEMEI Model's development in order to } \\
\text { increase the skills of thinking creatively and the } \\
\text { result study of students }\end{array}$ & 5 & 4 & 4 & 5 & 5 & 4.6 \\
\hline 2 & $\begin{array}{l}\text { The learning environments are arranged based on } \\
\text { the theoretical and empirical foundation from } \\
\text { latest journals, so it can be implemented logically } \\
\text { in KBM in the classroom }\end{array}$ & 5 & 5 & 4 & 5 & 5 & 4.8 \\
\hline
\end{tabular}

Based on the result of analysis data by expert judges that learning model which is developed gain score 4,38 for content validity and 4,27 for construct validity. If it is compared with the criteria of validity for a product that gain score $3,5 \leq$ model $<4,5$, it means that the learning model that has been developed is valid based on the results of content and construct validity. Therefore, the results of this research in which OPPEMEI Model has been developed show that (1) The rational development of OPPEMEI Model are comprehensive, (2) OPPEMEI Model is designed based on the latest knowledge, (3) The overview of OPPEMEI Model is appropriate with theoretical and empirical supports, (4)The syntax's sequences are logical, it can be done a teaching activities, an orientation in which the students practice their thinking skills creatively, (5) The consistency is in determining the basic competencies, indicators, and the goals of learning with KKNI competency (6) The social system can give a description about the parts of lecturers and students, the interaction between students, the interaction between lecturers and students logically, and consistently in achieving the goals of OPPEMEI Model's development, (7) The reactionary principles give a description the way how lecturers appreciate and respond the students' behavior during learning process logically and consistently to achieve the goals of OPPEMEI Model's development, (8) The support system and media logically can support the learning process smoothly by applying OPPEMEI Media, (9) The impact of instructional consistently aims to develop OPPEMEI Model and the impact of escort is unconsciously the effect from the implementation of syntax, social systems, reactionary systems, and supportive systems of OPPEMEI Model, (10) Learning environments are really important in supporting the achievement for the goals of OPPEMEI Model's development in order to increase the skills of 
thinking creatively and the result of students' study. In other words, relevant aspects are implied by Nieveen (1999) as a requisite of content validity that has been fulfilled with this model.

The selection of cognitive development theory that is correspond with the context of learning nowadays, it seems relevant in solving the learning's problems that happen because the variety of students. Thinking creatively is a authentic and reflective thought and can produce something that is complex and new (original). Gie (2003) gave limits that thinking creatively is a series of actions that are done by using their thought in order to create a new thought that comes from a series of memories that consist of ideas, information, concepts, experiences, and knowledge that exist in their mind as well. Creative thinking is mental activities in order to create connections continuously so it is produced an association product thinking appropriately (Diener et al. 2016; Evans, 1991).

The creative thinking skills identically focus in the strength of the brain. More than two decades ago, the results of researches about brain had brought astonishing results. The new way that are used in order to create and focus to the scientific ability, unconsciously has been found in every research areas of biology and psychology. For some people, the relation between these two researches are invisible, but if it is applied correctly then new scientific views into the utilization of the mind can help a person multiply and even optimize the power of mind. The reinforcement of minds that are meant: the power of studying, remembering, reading, listening and thinking (Stine, 2001).

Amabile and Gardner (as citen in Nur, 2014) emphasize that creative thinking is the key aspect of creative process. Ambile suggested that the key aspects of creative thinking are 1) Happy or entertained when the children have different opinions with the others and trying the deviate solutions from status quo (the social situations nowadays). (2) Combining knowledge that is from many kinds of area that separate before. (3) The students' ability to continue in solving the difficult and not attractive problems, (4) The ability to leave a method and come again with a fresh perspective (Nur, 2014).

Creative thinking according Coleman et al (1979) is "thinking which produces new methods, new concepts, new understanding, new inventions, and new work of art" (Rakhmat, 2005). This shows that creative thinking skills emphasize on regenerate toward what have existed. In other words, creative thinking is a kind of thinking that aims to create new ideas that are on the process according Jawwad (2014), it should fulfill four fundamental aspects namely: 
the high sensitivity towards kinds of problem, the high productivity in answering one question, the high elasticity in creating varieties of thinking, the high originality in creating varieties of thinking and the high originality in creating unique and new ideas. In the same way with those things, Munandar (2009) and Guilford (1981) explain that creative thinking skill include five aspects namely fluency, flexibility, originality, elaboration and evaluation.

Motivation is a physical and psychology conditions that exist in a person that controls the actions in the certain ways (Gates, et, al, 1954). Greenberg, 1966 (as cited in Djaalin, 2007), says that motivation is a process that are arousing, directing, and stabilizing the behavior in a certain purpose. The mental and human behaviors are a dimension that becomes a reference that is to be discussed into Psychology. According to Miller (1974), psychology is a knowledge that tries to explain, predict, and control the phenomena of mental and human behavior.

Based on thinking concentration theory explain that brain is an organ of human body that is complex and unique. The number of cells contained on the brain varies between 50 to 100 billion brain cells (Jensen, 2011). According to Grisewood (as cited in Syah, 2007), "A brain is the substance of the gray matter that located inside the coconut shell in which commonly has function as a control to the movements and work of the all physical organs as well as thinking tools". On the human brain, there are different parts that served some kinds of functions of mental, thinking, sexuality, memory, defense, emotion, and creativity. Based on constructivism theory explains about a person that understands toward something that has been known (Lorsbach dan Tobin, 1997). All of things that have been learned will be saved in the memories, based on the constructive ability of someone. The theory of socialculture is the last theory about motivation in which social-cultural theory comes from an art of psychologist Rusia Vygotsky (1986), who theories that human' activities happen under cultural control and the influence of the control really depends on what is done and thought.

\section{CONCLUSION}

Based on the explanation above then it can be concluded that the first is the content validity of Orientated Model, Extracting creative ideas, Investigation, Elaboration, Presenting Results, and Evaluating the Implementation (OPPEMEI) in terms of: (1) Rational Development Model, and (2) Model's design based on the latest knowledge. The second is measuring the validity of Extracting Creative Ideas Model, Investigation, Elaboration, Presenting the results, and Evaluating the Implementation (OPPEMEI) in terms of consistency aspects and logical 
components of model internally. Therefore, the results of this research in which OPPEMEI Model has been developed show that (1) The rational development of OPPEMEI Model are comprehensive, (2) OPPEMEI Model is designed based on the latest knowledge, (3) The overview of OPPEMEI Model is appropriate with theoretical and empirical supports, (4) The syntax's sequences are logical, it can be done teaching activities, an orientation in which the students practice their thinking skills creatively, (5) The consistency is in determining the basic competencies, indicators, and the goals of learning with KKNI competency. (6) The social system can give a description about the rules of lecturers and students, the interaction between students, the interaction between lecturers and students logically, and consistently achieving the goals of OPPEMEI Model's development, (7) The reactionary principles give a description the way how lecturers appreciate and respond the students' behavior during learning process logically and consistently to achieve the goals of OPPEMEI Model's development, (8) The support system and media logically can support the learning process smoothly by applying OPPEMEI Media, (9) The impact of instructional consistently aims to develop OPPEMEI Model.

\section{REFERENCES}

Albert, D.L., 2016. Teaching Critical and Creative Thinking Skills Through Problem-Solivng in High School Mathematics Classes.

Allen, D.E., Donham, R.S. \& Bernhardt, S.A., 2011. Problem-based learning. New Directions for Teaching and Learning, (128), pp.21-29.

Arends, R.I., 2012. Learning to Teach. 9th ed,

Bloom, B.S. et al., 1956. Taxonomy of Educational Objectives: The Classification of Educational Goals: Handbook I Cognitive Domain. New York, 16, p.207.

Bono, E. De, 2015. Lateral Thinking: Creativity Step by Step, Available at: http:/www.amazon.com/Lateral-Thinking-Creativity-Perennial-Libraryebook/dp/B003V1WTLI/ref=sr_1_1?s=books\&ie=UTF8\&qid=1403800683\&sr=1 1\&keywords=Lateral+Thinking: + Creativity+Step+by+Step.

Caine, R.N.C. and G., 1995. Reinventing Schools Through Brain-Based Learning. Educational Leadership, pp.43-47.

Diener, M.L. et al., 2016. Socioemotional Correlates of Creative Potential in Preschool Age Children: Thinking Beyond Student Academic Assessments. Creativity Research Journal, 28(4), pp.450-457. Available at: https:/www.tandfonline.com/doi/full/10.1080/10400419.2016.1229975.

Eagleton, S. \& Muller, A., 2011. Development of a model for whole brain learning of physiology. AJP: Advances in Physiology Education, 35(4), pp.421-426. 
Guilford, J.P. \& Christensen, P.R., 1973. The one-way relation between creative potential and IQ. The Journal of Creative Behavior, 7, pp.247-252.

Hmelo-silver, C.E., 2013. Creating a Learning Space in Problem-based Learning. Interdisciplinary Journal of Problem-based Learning, 7(1), pp.24-39.

Hong, J. et al., 2014. Computers \& Education Using a " prediction - observation - explanation " inquiry model to enhance student interest and intention to continue science learning predicted by their Internet cognitive failure. Computers \& Education, 72, pp.1-11. Available at: http://dx.doi.org/10.1016/j.compedu.2013.10.004.

Kauchak, D. \& Eggen, P., 2013. Education Psychology Windows on Classrooms_Ninth edition Ninth Edit., United States of America: Peachpit Press.

Lederman, J.S. et al., 2014. Meaningful assessment of learners' understandings about scientific inquiry - The views about scientific inquiry (VASI) questionnaire. Journal of Research in Science Teaching, 51(1), pp.65-83.

Lehtinen, A., 2016. Guidance Provided by Teacher and Simulation for Inquiry-Based Learning : a Case Study. Journal of Science Education and Technology. Available at: http://dx.doi.org/10.1007/s10956-016-9672-y.

LIN, C.-C. \& BRUCE, B.C., 2013. Engaging Youth in Underserved Communities Through Digital-Mediated Arts Learning Experiences for Community Inquiry. Studies in Art Education, 54(4), pp.335-348.

Lin, W.-L. \& Shih, Y.-L., 2016. Designing EEG Neurofeedback Procedures to Enhance Openended versus Closed-ended Creative Potentials. Creativity Research Journal, 28(4), pp.458-466. Available at: https://www.tandfonline.com/doi/full/10.1080/10400419.2016.1229979.

Moreno, R., 2013. Educational Psychology. Journal of Chemical Information and Modeling, 53(9), pp.1689-1699.

Nuttariya, K.-O. et al., 2012. Designing Framework of Multimedia Learning Environment to Enhance Problem Solving Transfer. Procedia - Social and Behavioral Sciences, 46, pp.3421-3425. Available at: http://dx.doi.org/10.1016/j.sbspro.2012.06.077.

Osgood-Campbell, E., 2015. Investigating the educational implications of embodied cognition: A model interdisciplinary inquiry in mind, brain, and education curricula. Mind, Brain, and Education, 9(1), pp.3-9.

Soltis, R. et al., 2015. Process-oriented guided inquiry learning strategy enhances students' higher level thinking skills in a pharmaceutical sciences course. American journal of pharmaceutical education, 79(1), p.11.

Wijnia, L. et al., 2016. University teacher judgments in problem-based learning: Their accuracy and reasoning. Teaching and Teacher Education, 59, pp.203-212. 